\title{
De-Europeanisation of UK regulatory governance and the future UK-EU trade relationship
}

\author{
Adam Cygan ${ }^{1}$
}

Published online: 31 January 2020

(C) The Author(s) 2020

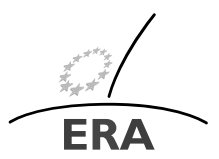

EUROPÄISCHE RECHTSAKADEMIE ACADEMY OF EUROPEAN LAW ACADEMIE DE DROIT EUROPEEN ACCADEMIA DI DIRITTO EUROPEO
TRIER - TREYES - TREVIRI

\begin{abstract}
With the exception of obligations during the transition period until the 31 December 2020, the UK will leave the EU Single Market and will need to negotiate a new regulatory framework for its future trade relationship with EU. The primary issue for the UK will be how much market access it will want to secure and what regulatory obligations will it be required to comply with in return for this. During EU membership, integration led to the UK's regulatory framework becoming Europeanised which ensured the removal of trade barriers and provided for a level playing field of regulatory governance through harmonisation of technical standards and public policy objectives such as environmental standards or employment protection. As part of the future UK-EU trade relationship, the EU will be likely to insist on continuity of high levels of regulatory alignment, but the UK has indicated that it wishes to diverge from EU rules, leaving significant challenges for the UK-EU trade negotiations. This article considers the opportunity for the UK to de-Europeanise its regulatory governance after Brexit and whether and to what extent this will be compatible with negotiating a comprehensive trade agreement with the EU.
\end{abstract}

Keywords Brexit · Regulatory governance $\cdot$ Europeanisation $\cdot$ UK-EU trade relationship

The Author would like to acknowledge the support of the ESRC for funding research underpinning this article through its 'UK in Changing Europe Initiative' (Brexit Priority Grant ES/R000646/1 'Parties, Parliament and the Brexit Process'). I would like thank Dr John Paul Salter for his comments on an earlier draft of this article. The usual disclaimer applies.

A. Cygan

1 Professor of EU Law, University of Leicester, Leicester, UK 


\section{Introduction}

On 31 January 2020, the UK left the EU and in the words of the White Paper on the Future Relationship 'took back control of its money, laws and borders'. ${ }^{1}$ The European Union Withdrawal Act 2018 (EUWA) repealed the European Communities Act 1972 (ECA) ending the supremacy of EU law within the UK, subject to the transition period. The EUWA, through Retained EU law, converted much of the body of EU law into UK law and though based on EU law, it will be UK courts which exclusively interpret and apply Retained EU law.

Brexit means the UK Parliament is not bound by future laws made by EU institutions and repatriates regulatory control to the UK Parliament. Parliament, subject to obligations during the transition period, may repeal or amend Retained EU law which could mean that, for example, UK employment laws diverge from EU standards. However, Brexit, as this article argues, does not mean that the UK enters regulatory isolation questioning how rapidly, and to what extent, the UK will de-Europeanise its governance frameworks especially if the UK wants to maximise Single Market access under a new trade agreement. ${ }^{2}$ In order to agree what the non-binding Political Declaration accompanying the Withdrawal Agreement describes as a 'an ambitious, wide-ranging and balanced economic partnership' ${ }^{3}$ the UK could be required to continue to accept regulatory alignment with existing and future EU regulatory norms, including technical standards and public policy objectives such as employment protection and environmental standards. Far from taking back control, Brexit could mean that, for years to come, the UK becomes a 'rule taker'.

There are many aspects to the future relationship covering Single Market access including the provision of services, but this article considers regulatory governance only in the context of a future trade relationship. This is because the White Paper identifies a regulatory framework for trade as a UK negotiating priority, ${ }^{4}$ and because the trade in goods excludes free movement of people, which the UK insists will not form any part of the future UK-EU relationship. ${ }^{5}$ This article draws upon research collected as part of an Economic and Social Council-funded project. Drawing upon non-attributable interviews with UK parliamentarians and parliamentary officials, Norwegian parliamentary officials and stakeholder consultation through seminars co-organised with the Industry and Parliament Trust, ${ }^{6}$ this article contributes to

\footnotetext{
${ }^{1}$ Cm 9593 (2018), The Future Relationship between the United Kingdom and the European Union [9], p. 1.

${ }^{2}$ Birch and Bulmer [3], p. 862 argue that Europeanisation of UK governance commenced even before the UK joined the EEC in 1973.

${ }^{3}$ Political Declaration setting out the framework for the future relationship between the European Union and the United Kingdom (hereafter the 'Political Declaration') [32], para. 3.

${ }^{4} \mathrm{Cm} 9593$ [9], p. 14, para. 7.

${ }^{5}$ Weatherill [36], p. 164 argues negotiating any agreement on services is likely to provide more complicated than for goods and questions whether within the governance of the Single Market, it is possible to separate goods and services as the government has done in the negotiations.

${ }^{6}$ As part of the research under the ESRC grant the Author undertook non-attributable interviews with UK parliamentarians and parliamentary officials and Norwegian parliamentary officials. In addition, together with Industry and Parliament Trust, a politically independent charity based in the UK Parliament, the Au-
} 
the literature on post-Brexit regulatory governance of UK-EU trade in three ways. Firstly, the article questions whether regulatory divergence will be compatible with Single Market access under a comprehensive trade agreement. The UK commences trade negotiations from a very high level of regulatory alignment of technical standards and public policy which the EU has indicated, as its political preference, that the UK continues to abide by within a trade agreement to ensure a level playing field. ${ }^{7}$

Secondly, the article analyses the Political Declaration as the document which sets the parameters for trade negotiations and explores the potential regulatory impact of the UK diverging from EU laws on Single Market access. In particular, the article analyses the potential effects on Single Market access if a principle of mutual recognition were to be excluded from the regulatory framework of the future trade relationship, as would almost certainly be the case with a 'bare bones' Canada-style Free Trade Agreement (FTA).

Finally, the article considers some of the possible institutional challenges which may arise for management and oversight of a trade agreement. In this context, far from being outside the control of the Court of Justice of the European Union (CJEU), the autonomy of the EU legal order could mean that the UK may be required to accept Europeanised judicial interpretations of governance principles for goods in order to secure market access.

\section{Brexit and the Europeanised system of governance}

The primary features of Europeanisation have been the transfer of competences to EU institutions, centralisation, legislative harmonisation and regulatory convergence. Enforcement of EU regulatory standards has been achieved through national authorities and courts, together with interpretative support from the CJEU. ${ }^{8}$ However, Brexit and its mantra of 'taking back control' means the UK Parliament regains legislative sovereignty from EU institutions and freedom to determine its own regulatory standards, including whether to remain aligned with or diverge from EU laws. As a regulatory theory, Brexit is an experimental form of governance. After forty-six years, the legal and political certainties of EU regulatory governance, which enabled free movement and market access, will be replaced by a UK regulatory framework where free movement and unhindered Single Market access are excluded.

With the UK outside the formal process of Europeanisation it is unclear whether, and to what extent, the maintenance of this high degree of Europeanisation will be possible or politically desirable. But, this may be a decision that is not fully within the UK's political control because even if the UK opts for an FTA, there is likely

thor co-organised stakeholder consultation seminars which brought together MPs, Peers, business leaders and academics. The seminars, covering a range of policy areas impacted by Brexit, considered issues of regulatory governance and Single Market access post Brexit as well as identifying regulatory priorities for UK lawmakers and business.

${ }^{7}$ EU Council Negotiation Guidelines for the future UK-EU relationship, EUCO XT 20001/18, 23 March 2018 [20]. This includes environmental protection and employment rights; Menon [30] considers this requirement an attempt by the EU to restrain the UK as a commercial competitor.

${ }^{8}$ Boucon [6], p. 172. 
to remain a powerful informal impact of EU rules. Those countries located in the immediate neighbourhood of the EU are particularly unable to ignore its rules and regulations ${ }^{9}$ and for the UK this could require maintaining closer regulatory alignment than politically desired in return for market access.

\subsection{Europeanisation and the transfer of competences}

The Treaties confer no general competence to harmonise national laws and Article 5 TEU states that the EU is competent only where so provided by the Treaties. ${ }^{10}$ Some 'non-economic' activities of the Member States have remained outside the competence of EU law for example, the provision of State education and health care services. However, even these competences have not been wholly immune from EU regulatory principles and in judgments such as Watts ${ }^{11}$ and Bidar, ${ }^{12}$ the CJEU held that the non-discrimination principle in Article 18 TFEU, or the Citizenship provisions of Articles 20-22 TFEU must be applied to the delivery and consumption of public services. ${ }^{13}$ Similarly, the Treaty provisions may apply, for example, the application of free movement and competition rules to sport or healthcare, even though the EU does not exercise direct legislative competence in the field. According to Armstrong, this ubiquitous effect of EU law has led to EU regulatory policy exhibiting 'highalthough not uniform-levels of Europeanisation and domestic regulatory policy has adapted to the impact of this Europeanisation'. ${ }^{14}$

Europeanisation has created a shared policy and legislative agenda which Member States implement and has experimented with diverse modes of governance in the pursuit of integration. ${ }^{15}$ de Búrca and Scott, described the modern shift to new governance methods as encompassing a wide range of processes and practices that have a normative dimension but do not operate primarily, or at all, through the formal EU law-making mechanisms involving traditional command-and-control legal institutions. ${ }^{16}$ This included, the open method of coordination and more recently in the aftermath of the financial crisis, economic governance which is shared between the EU and Member States. Europeanisation therefore developed policies at the EU level which were incorporated by Member States into domestic policies. In the context of Brexit, Armstrong considers these diverse governance processes have created a 'highly legalised' Europeanised framework of governance within the UK which was enforced by UK and EU institutions. ${ }^{17}$

\footnotetext{
${ }^{9}$ Kukovec [27].

${ }^{10}$ Weatherill [34], p. 233.

${ }^{11}$ Case C-372/04 Watts ECLI:EU:C:2006:325.

${ }^{12}$ Case C-209/03 Bidar ECLI:EU:C:2005:169.

${ }^{13}$ Cygan [14], p. 545.

${ }^{14}$ Armstrong [1], p. 1100; Dehousse [16], pp. 209-210.

${ }^{15}$ Dehousse [16], p. 211.

${ }^{16}$ de Búrca and Scott [8], p. 522; Walker and de Búrka [33], pp. 526-528.

${ }^{17}$ Armstrong [1], p. 1100.
} 
Since the European Commission's White Paper on EU Governance in $2001,{ }^{18}$ the issue of governance has been an EU imperative. The expression 'European governance' designates a distinct Europeanised framework of regulation with a body of harmonised rules, procedures and enforcement practices. In the context of the 2001 Governance White Paper, the Commission's focus remains on establishing a governance framework which provides effective regulation, that is least intrusive and removes regulatory burdens to enable cross border economic activity while simultaneously delivering tangible economic and social benefits for EU citizens. In the formation of legislative proposals, in addition to removal of fiscal and non-fiscal barriers the Commission considers social and public policy objectives and is instructed to aim for a high level of protection for health, safety, environmental and consumer protection in proposals based upon Article 114(3) TFEU. To this extent, through the Better Regulation Agenda the Commission has adopted a modus operandi of stakeholder consultation, transparency and compliance with the principles of proportionality and subsidiarity in order to enhance public perceptions of value-added EU policy outcomes and improved legitimacy of EU governance processes. ${ }^{19}$

\subsection{Europeanisation of UK governance}

In response to Europeanisation of governance frameworks Member States have dovetailed with EU principles, standards and practices and applied them to their own domestic governance arrangements. ${ }^{20}$ In the UK policy and legislative cycle, Europeanisation was received via the Better Regulation Framework ${ }^{21}$ which embraced and expanded practices such as stakeholder consultation and Impact Assessments. ${ }^{22}$ The latter incorporated EU public policy objectives and considered the economic and social impact of a UK legislative proposal through the lens of EU law and policy. In the context of participation in EU policy formulation and implementing EU law in the UK, the UK's Better Regulation Framework was substantively Europeanised. ${ }^{23}$ Firstly, at the stage of EU policy formulation successive UK governments recognised the importance of influencing the EU policy cycle at the very early stages moving upstream to make representations to the Commission, as well building alliances with other Member States. ${ }^{24}$

Secondly, with respect to implementation of EU laws the objective was that UK regulatory frameworks complied with the requirements of harmonised EU regulatory standards and the principle in Article 4(3) TEU of sincere cooperation. A purposive interpretation of Article 4 (3) TEU suggests it places regulatory limitations upon

\footnotetext{
${ }^{18}$ COM (2001) 428 European Governance: A White Paper [10].

${ }^{19} \mathrm{COM}$ (2003) 71 final Updating and simplifying the Community acquis [11]; House of Lords (2005). Ensuring effective regulation in the EU. 9th Report of Session 2005-2006 [22]; See de Búrca and Scott [8].

${ }^{20}$ Knill and Lehmkuhl [26], pp. 263-264.

${ }^{21}$ Department for Business, Energy and Industrial Strategy, Better Regulation Framework (August 2018); Birch and Bulmer [3], p. 866.

${ }^{22}$ Harlow and Rawlings [21], p. 277.

${ }^{23}$ Birch and Bulmer [3], p. 873.

${ }^{24}$ HM Government, Better Regulation Manual (2013), para. 1.5.11.
} 
Member States which, in the UK, meant that Impact Assessments required formal confirmation that UK legislative proposals complied with EU laws, irrespective of whether the legislation implemented EU law, or concerned the exercise of an exclusive UK competence. ${ }^{25}$

Thirdly, in terms of implementation of EU laws in the UK, this was achieved, as far as possible, through adopting the 'copyout' technique, which provided for direct transposition as the preferred means of legislative implementation for EU directives, in order to avoid risks of judicial enforcement ${ }^{26}$ arising from incorrect implementation or over-regulation. ${ }^{27}$

The Europeanisation of UK regulatory governance impacted UK policy-making, its political process and judicial enforcement because of the fundamental constitutional principles of EU law which guaranteed supremacy ${ }^{28}$ and direct effect. ${ }^{29}$ Both principles restricted regulatory autonomy ${ }^{30}$ to the extent that UK regulatory frameworks complied with minimum EU standards. ${ }^{31}$ Yet, EU membership did not prevent the UK from pursuing a domestic regulatory agenda which imposed higher domestic standards, subject to compliance with Article 4(3) TEU and the principle of nondiscrimination, thereby confirming Armstrong's assertion that EU regulatory policy exhibits 'high though not uniform levels of Europeanisation'. ${ }^{32}$

In practice, compliance with minimum EU standards did not prevent UK governments from legislating to deliver on manifesto commitments in, for example, public health which prohibited all forms of tobacco advertising and point of sale restrictions, ${ }^{33}$ notwithstanding that the Tobacco Advertising Directive restricted advertising of tobacco products only in those circumstances where there was the existence of a cross border dimension. ${ }^{34}$ Despite the centralising nature of EU governance, UK regulatory frameworks continued to evolve to reflect domestic political priorities while simultaneously becoming Europeanised. Thus, and depending upon the depth and scope of the future trade relationship, this form of regulatory co-existence could provide a model for regulatory governance which, as the Political Declaration states,

${ }^{25} \mathrm{HM}$ Government, Guiding Principles for EU Legislation (2013), Operating Principles, para. 5. This requirement for implementing EU law in the UK also confirms Armstrong's [1] assertion of the 'ubiquitous effect of EU law'.

${ }^{26}$ A key part of this enforcement has been the Francovich principle of State liability which the EUWA does not retain as part of the enforcement regime for Retained EU law. See EUWA Schedule 1 paragraphs 4-5.

${ }^{27}$ HM Government, Transposition Guidance: How to implement European Directives effectively (February, 2018), pp. 10-12.

${ }^{28}$ Case C-64 Costa v E.N.E.L ECLI:EU:C:1964:66.

${ }^{29}$ Case 25/62 van Gen den Loos ECLI:EU:C:1963:1.

${ }^{30}$ For the constitutional and regulatory impact in the UK of the supremacy of EU law see Case C-213/89 Factortame ECLI:EU:C:1990:257.

${ }^{31}$ Harlow and Rawlings [21], p. 277.

${ }^{32}$ Armstrong [1], p. 1102.

${ }^{33}$ See Tobacco Promotions and Advertising Act (2002) as amended and Health Act 2009.

${ }^{34}$ Directive 2003/33/EC of the European Parliament and of the Council of 26 May 2003 on the approximation of the laws, regulations and administrative provisions of the Member States relating to the advertising and sponsorship of tobacco products [18]. 
recognises the existence of 'separate markets and distinct legal orders'. ${ }^{35}$ However, as discussed below, such a model would arguably still require some element of mutual recognition and regulatory alignment of minimum standards, most probably reflecting EU regulatory principles, in order to maximise market access. ${ }^{36}$

Given that the extent of integration varies across policy areas EU regulatory governance has not been confined to any single mode of governance. Accordingly, it would not be incorrect to assume that, the greater the depth, complexity and scale of EU integration, the longer the time period for any de-Europeanisation to occur. According to Burns et al., in the case of environmental policy where regulatory governance in the UK is multi-level and has, what the authors describe as, a 'messier, devolved structure', de-Europeanisation is less likely, at least in the short term. ${ }^{37}$ However, this would be by contrast with employment policy, where regulatory governance has been significantly centralised at the EU level. For Copeland this regulatory strategy would suggest that the existence of centralised EU legislation may make it easier to 'unpick' through UK primary or secondary legislation as employment policy is a centralised UK policy. ${ }^{38}$

Copeland's argument is particularly convincing when we consider the content of the New Withdrawal Agreement and non-binding Political Declaration negotiated by Boris Johnson. ${ }^{39}$ Unlike the Withdrawal Agreement negotiated by his predecessor, Theresa May, Johnson's Agreement does not include legally binding provisions to maintain regulatory alignment with existing or future EU employment laws. Instead, under Johnson's Agreement, employment policy has only been included in the Political Declaration, thereby offering no legal guarantees for future alignment of employment laws. In the Queen's Speech after the 2019 General Election won by the Conservative Party, it was proposed that the government would legislate separately, outside of the Withdrawal Agreement Act 2020 (WAA) for future employment protection but it was not made clear what this will entail. ${ }^{40}$ This legislative strategy would appear to chime with Copeland's argument that, once competence in employment policy is repatriated this will enable the UK government to isolate it from other parts of Retained EU law and amend or repeal laws considered too burdensome or unnecessary. ${ }^{41}$

Though employment protection may be vulnerable to de-Europeanisation postBrexit, there should not be an expectation that the UK will undergo a systematic process of uniform and rapid de-Europeanisation of regulatory governance. Fortysix years of UK membership has Europeanised ${ }^{42}$ UK laws and impacted upon the

\footnotetext{
${ }^{35}$ Political Declaration, para. 21.

${ }^{36}$ Menon [30].

${ }^{37}$ Burns et al. [7], p. 284.

${ }^{38}$ Copeland [13], p. 1133.

${ }^{39}$ Available at https://www.gov.uk/government/publications/new-withdrawal-agreement-and-politicaldeclaration. (Accessed 19 October 2019).

${ }^{40}$ Queens' Speech 19 December 2019. Available at https://www.gov.uk/government/speeches/queensspeech-december-2019. (Accessed 20 December 2019).

${ }^{41}$ Copeland [13], p. 1134.

${ }^{42}$ Birch and Bulmer [3], p. 868.
} 
domestic policy agenda and institutional architecture. As Burns et al. argue, harmonisation of EU environmental governance has markedly influenced UK environmental policy $^{43}$ and brought about the reorganisation of government structures within the UK's constitutional and devolution settlement in order to ensure that policy delivery is seamless, and Brexit should not be considered as a catalyst that will immediately change this. ${ }^{44}$

Furthermore, EU regulatory governance is underpinned by administrative and judicial coherence ${ }^{45}$ which includes an effective capacity for oversight and enforcement, at the EU level, which the UK will need to replicate. The creation of dedicated EU Agencies, which enforce EU rules uniformly across the Member States, dispensed with need for UK enforcement agencies, as well as the requirement to establish mechanisms for guaranteeing regulatory equivalence with Member States. Not only is this centralised form of governance efficient, if the UK accepts regulatory alignment in return for market access, it is likely to be insisted upon by the $\mathrm{EU}^{46}$ as a pre-requisite for regulatory governance within the future trade relationship. ${ }^{47}$

\section{The EU Withdrawal Act 2018 —ending the supremacy of EU law}

The EUWA repeals the ECA on exit day and would have entered in to force irrespective of whether the UK and EU had concluded a Withdrawal Agreement. The EUWA's constitutional purpose is to remove the need, as far as possible, for Parliament to enact tailored legislation replicating rights within the EU acquis ${ }^{48}$ and provide regulatory continuity. The EUWA repeals the ECA, subject to the provision of section 1 of the WAA which revives certain provisions of the ECA for the purposes of transition which allow for the continued supremacy of EU law. The joint legal effect of the EUWA and WAA demonstrates that though the UK left the EU institutions on 31 January 2020, this does not mean an immediate end to the supremacy of EU law within the UK Constitution.

This is further reinforced by a novel constitutional feature of the EUWA that, under s. 4(1), a principle of supremacy is preserved for Retained EU law. Legally, this means Retained EU law is supreme over pre-exit day UK law further reinforcing the continuance of EU regulatory norms within the UK. Moreover, under s. 6(3), UK courts will consult pre-exit CJEU judgments to aid interpretation of the application of

\footnotetext{
${ }^{43}$ See, for example, the Climate Change Act 2008.

${ }^{44}$ Burns et al. [7], p. 277.

${ }^{45}$ Bertea [2], p. 157.

${ }^{46} \mathrm{See}$, for example, an interview in the Irish Times with EU Commissioner Phil Hogan on 30 December 2019 [24]. Hogan stated: 'Too much of the debate in the UK over the past four years was based on the false notion that it is possible to make a clean-break Brexit while retaining all the benefits of EU membership. Now that the political deadlock at Westminster is broken the next phase of Brexit needs to be based on realism and hard facts. Any 'having our cake and eat it' rhetoric will not fly'.

${ }^{47}$ Para. 11 EU Council Negotiation Guidelines for the future UK-EU relationship, EUCO XT 20001/18, 23 March 2018 and the Political Declaration, para. 23.

${ }^{48}$ Elliot and Tierney [19], p. 39.
} 
Retained EU law and resolve conflicts between it and pre-exit UK legislation. Postexit CJEU judgments, are not binding on UK courts, but may provide persuasive authority for the Supreme Court which, under section 6(2) may consider post-exit CJEU judgments if this promotes judicial clarity. While Brexit means an end to the direct jurisdiction of the CJEU, the EUWA maintains an Europeanised legal framework, probably beyond the transition period and preserves a significant degree of interdependence between the two jurisdictions. ${ }^{49}$ This will entail continued acceptance and enforcement by UK courts of the Europeanised regulatory norms and standards within Retained EU law that Parliament implemented throughout EU membership and which have shaped domestic UK law and policy since 1973. If the UK wishes to diverge from these Europeanised regulatory norms and standards, Parliament will have to explicitly legislate in order to do so.

\subsection{Regulatory governance and the EU Withdrawal Act 2018}

The EUWA is the starting point from which to understand the principles and objectives of future regulatory governance and whether, and to what extent, it may remain Europeanised. Firstly, the EUWA does not define the future relationship nor does it make it inevitable that the UK will steer a path towards a uniform process of deEuropeanisation concurrent across policy areas. The EUWA repeals the ECA and cuts of the 'conduit pipe' by which EU law enters the UK legal order, ${ }^{50}$ but it does not prescribe that Retained EU law undergo future amendment which is ultimately a political choice for Parliament. However, the policy and legal effect of the EUWA, together with the Political Declaration, do provide some clues with respect to the possible choices and challenges for post Brexit regulatory governance, most notably whether and to what extent the UK should pursue regulatory alignment in order to secure Single Market access.

Post Brexit, UK regulatory frameworks are longer subject to the fundamental principles of EU constitutional law and will operate outside the EU's governance and institutional architecture. But this should not necessarily mean that what Copeland describes as a 'disengagement' from the EU's institutional architecture will necessarily lead to an immediate de-Europeanisation of UK governance frameworks. ${ }^{51}$ This is certainly true if the regulatory consequences of Brexit within the EUWA are considered which is to avoid a 'regulatory cliff edge' on exit day. Though wholly domestic law, applied by UK courts, without the possibility of interpretative references to the CJEU under Article 267 TFEU, Retained EU law will be applied by UK courts subject to interpretations found within pre-Brexit CJEU case law.

Moreover, in recognition that through integration national laws and EU law have become what Laenarts described as 'interlocking legal orders' which show 'mutual

\footnotetext{
${ }^{49}$ Cygan, Lynch and Whitaker (2020, forthcoming) [15].

${ }^{50} R$ v Secretary of State for Exiting the European Union ex parte Miller and others [2017] UKSC 5 para. 84 .

${ }^{51}$ Copeland [13], p. 1126; Burns et al. [7], p. 285; Jordan et al. [25], pp. 797-798.
} 
respect for each other and based upon equivalent levels of protection of the rule of law, 52 the EUWA does not repeal EU principles, values and standards which will continue to regulate the application of Retained EU law for the foreseeable future. This raises an expectation that these values and standards may also form some part of the future trade relationship and the Political Declaration recognises this by stating that 'the future relationship should be underpinned by shared values such as the respect for and safeguarding of human rights and fundamental freedoms, democratic principles, the rule of law and support for non-proliferation'. ${ }^{3}$ This is further reinforced by the proposition that throughout UK membership of the EU, UK law and EU law have undergone substantial cross-fertilisation, with general principles integral to Single Market governance, for example proportionality, having impacted domestic law and practice. The EUWA retains the general principles of EU law in the application and Schedule 1 provides that general principles will remain relevant in the interpretation of Retained EU law, subject to these general principles being recognised by the CJEU on exit day. ${ }^{54}$ Given the importance of proportionality to regulation of the Single Market, its inclusion in the trade relationship should be considered as a negotiation priority for the EU as a principle that regulates market access between the UK and EU, including the exercise of public policy justifications by either party. ${ }^{55}$

The continuation of the UK's Europeanised regulatory framework is further entrenched through Parliament's ratification of the Withdrawal Agreement in the WAA. The WAA provides for a transition period, to the 31 December $2020,{ }^{56}$ during which time the UK remains bound by EU laws, abides by EU regulatory frameworks and implements new EU rules. Beyond transition, the arrangements for management and oversight of any future trade relationship are uncertain and would largely depend upon the depth and scope of that relationship and the extent to which this requires the UK to domesticate future EU laws as part of a common rulebook. Even if the UK opts for a Canada-style FTA with minimal regulatory alignment, it is difficult to envisage the UK departing rapidly from the regulatory framework of Retained EU law, not least because the case for voluntary regulatory continuity would remain strong as the imperative of market access will not change. For the UK, this should mean that, in its approach towards the negotiations, there ought to be no legal or political distinction between avoiding a regulatory cliff-edge arising from a 'no-deal' Brexit and avoiding a regulatory cliff-edge because of a failure to conclude a future trade relationship by the end of the transition period, which secures market access and protects just in time supply chains. 57

\footnotetext{
${ }^{52}$ Laenarts [28], p. 906.

${ }^{53}$ Political Declaration, para. 6.

${ }^{54}$ Schedule 1 paragraphs $2-4$.

${ }^{55}$ Political Declaration, paras. 3-5 and para. 23. See also Menon [30].

${ }^{56}$ Though the WAA does include a provision which prevents the extension of the transition beyond this date leaving only eleven months for the UK and EU to agree and ratify a new trade agreement.

${ }^{57}$ See further the interview in the Irish Times with EU Commissioner Phil Hogan on 30 December 2019.
} 


\subsection{Regulatory challenges for the future trade relationship-can the UK have its cake and eat it? ${ }^{58}$}

The 2018 White Paper on the Future UK-EU Relationship, ${ }^{59}$ was published whilst Theresa May was Prime Minister. Though it has been not been revised since Boris Johnson became Prime Minster, the Political Declaration accompanying the Withdrawal Agreement does indicate some shift in regulatory priorities for the UK, with a greater emphasis upon autonomy to set regulatory standards in public policy objectives and regulatory divergence. ${ }^{60}$ However both the White Paper and Political Declaration do recognise that, post transition, there may remain areas of governance in relation to goods, where UK and EU laws would be likely to remain aligned. The unanswered questions are which laws and to what extent?

The White Paper suggested that the UK could adopt EU laws either voluntarily or because they form part of a 'common rulebook' ${ }^{61}$ In the case of voluntary adoption, or what is referred to as 'dynamic alignment', this would presumably occur in order to secure the best possible market access and could include the UK continuing to align itself with EU laws which regulate public policy objectives such as employment rights, consumer and environmental protection, but this is unlikely. More probable, is that the EU will insist that regulatory governance in goods formally encompasses alignment with public policy objectives in order to ensure a regulatory level playing field. ${ }^{62}$ While this is a potential source of friction in the future relationship negotiations, especially if the UK only wants to negotiate a Canada-style FTA, it may also suggest a concern on the EU side of whether a commercial competitor can really be a close trading partner outside the organisation.

The pressure for the UK to accept EU rules could be particularly strong especially if regulatory standards of repatriated competences remain un-amended within Retained EU law and continue to be interpreted by UK courts in line with CJEU judgments. As Article 12 of the European Council's Guidelines on the future UK-EU relationship spell out:

'Given the UK's geographic proximity and economic interdependence with the EU27, the future relationship will only deliver in a mutually satisfactory way if it includes robust guarantees which ensure a level playing field. The aim should be to prevent unfair competitive advantage that the UK could enjoy through undercutting of levels of protection with respect to, inter alia, competition and state aid, tax, social, environment and regulatory measures and practices'.63

This EU 'red line' will be difficult for the UK to push back on during negotiations, but, at the same time, the Political Declaration is vague on precisely how

\footnotetext{
${ }^{58}$ Boris Johnson is reported to have said that his policy on 'cake' is 'pro having it and pro eating it too'. See 'Can Boris Johnson have his cake and eat it? The Times 9 September 2019. Available at https://www. thetimes.co.uk/article/can-johnson-have-his-cake-and-eat-it-8wb6hkmfx. (Accessed 12 September 2019).

${ }^{59} \mathrm{Cm}$ 9593, 2018.

${ }^{60}$ Political Declaration, para 21.

${ }^{61} \mathrm{Cm}$ 9593, p. 8 .

${ }^{62}$ See, for example, the statement of German EU Minister Michael Roth of 12 November 2018. (Accessed 12 August 2019).

${ }^{63}$ This statement is repeated and expanded upon in Article 77 of the Political Declaration.
} 
much regulatory alignment the UK is prepared to accept with respect to public policy objectives which the UK views as ancillary to a trade agreement. ${ }^{64}$ The Political Declaration states that 'the Parties will retain their autonomy and the ability to regulate economic activity according to the levels of protection each deems appropriate in order to achieve legitimate public policy objectives such as public health, animal health and welfare, social services, public education, safety, the environment including climate change, public morals, social or consumer protection, privacy and data protection, and promotion and protection of cultural diversity'. However, this statement must also be considered through the lens of EU integration and maintaining the integrity of the Single Market. In this case, as Article 77 of the Political Declaration implies, the EU would probably be looking for a very narrow interpretation of regulatory autonomy exercised by the UK, especially when it concerns reducing regulatory burdens in, environmental or consumer protection or taxation, all which could place EU business at a competitive disadvantage. ${ }^{65}$

Moreover, in terms of Single Market regulation, the public policy objectives included in the Political Declaration are already narrowly interpreted by the CJEU in its case law on the free movement of goods. ${ }^{66}$ While these public policy objectives reflect both distinctly and indistinctly applicable justifications, ${ }^{67}$ under EU law, it is established in the CJEU's case law $^{68}$ and the Commission's enforcement regime ${ }^{69}$ that the EU only tolerates justifications to the free movement rules where a Member State is able to demonstrate the existence of an explicit public policy objective which is proportionate. ${ }^{70}$ It would not be unreasonable to assume, that in order to protect the Single Market from unfair competition, the EU is likely to insist on maintaining

${ }^{64}$ Institute for Government Trade after Brexit: Options for the UK's relationship with the EU [23], p. 17. (Accessed 18 October 2019). See also Menon [30].

${ }^{65}$ Arguably the Political Declaration explicitly rejects the UK abandoning EU regulatory standards at the end of the transition period. Article 77 provides that 'To that end, the Parties should uphold the common high standards applicable in the Union and the United Kingdom at the end of the transition period in the areas of state aid, competition, social and employment standards, environment, climate change, and relevant tax matters. The Parties should in particular maintain a robust and comprehensive framework for competition and state aid control that prevents undue distortion of trade and competition; commit to the principles of good governance in the area of taxation and to the curbing of harmful tax practices; and maintain environmental, social and employment standards at the current high levels provided by the existing common standards. In so doing, they should rely on appropriate and relevant Union and international standards (emphasis added), and include appropriate mechanisms to ensure effective implementation domestically, enforcement and dispute settlement.'

${ }^{66}$ See, for example, Case C-231/83 Cullet EU:C:1985:29; Case C-72/83 Campus Oil EU:C:1984:256.

${ }^{67}$ See Case 120/78 Cassis de Dijon EU:C:1979:42 and further Leucht [29].

${ }^{68}$ See for example, Commission v Ireland EU:C:1982:402; Joined Cases 60\&61/84 Cinéthèque SA and others EU:C:1985:329. In Cinéthèque the Court stressed that any restriction on free movement must be proportionate.

${ }^{69}$ See, for example, Commission v France EU:C:1997:595.

${ }^{70}$ Cf. Case C-40/82 Commission v UK EU:C:1984:33 with Case C-276/91 Keck and Mithouard EU:C:1993:905 on what constitutes a clear public policy objective. Leucht [29] highlights the importance of proportionality as part of judicial policy in the regulation of the free movement of goods when assessing both distinctly and indistinctly measures, pp. 207-208. See also, Weatherill [36], p. 136. 
Europeanised interpretations of these public policy justifications within the future relationship. $^{71}$

Should the UK seek to negotiate only a Canada-style FTA and exclude public policy objectives from a future trade relationship, then a political strategy would probably be required which demonstrates an unwillingness to continue to accept Europeanised standards. For example, this could include making appropriate legislative amendments to relevant provisions of Retained EU law, which indicate a clear public policy intention that the UK is pursuing regulatory divergence. Nevertheless, in the light of the robust Council Negotiating Guidelines, the existing body of CJEU case law and the EU's insistence that a future trade agreement should not undermine the integrity of the Single Market, the UK may not be able to eat its cake after all. With a bare bones FTA and without regulatory alignment on public policies, which ensure a level playing field, Single Market access will be severely restricted. On this analysis it must be doubtful whether any UK strategy towards the negotiations would sway the EU from what would appear to be constitutional, economic and political imperatives for regulatory alignment on public policy objectives as part of a negotiating strategy to maintain the integrity of the Single Market and ensure a level playing field. ${ }^{72}$

\subsection{Mutual recognition and future market access}

As part of the future trade relationship, the 2018 White Paper proposed a 'common rulebook' in trade and goods as a mechanism which would maximise UK market access. However, this would require the UK to adopt applicable new EU laws and enforce EU provisions in UK courts and would be subject to criticism that the UK has become a 'rule taker' and would be only included as part of a comprehensive trade agreement. The UK and EU have expressed the basic principles of a future trade relationship, in the Political Declaration, which indicate that it should be a rulesbased relationship, binding on both parties and require that the future governance arrangements include oversight processes to ensure correct application of laws by both parties. ${ }^{73}$ Within existing modes of EU governance this would utilise institutions, processes and enforcement mechanisms that are the characteristics of the EU's hierarchical form of governance. ${ }^{74}$ In terms of a rules-based relationship, perhaps of most significance for a common rulebook is that it would almost certainly include the maintenance of some degree of mutual recognition between UK and EU regulatory standards to facilitate market access.

The Political Declaration acknowledges that mutual recognition will form part of the regulatory framework for the trade in goods, but rather than referring to mutual recognition per se, the Declaration implies this by stating that in 'facilitating the movement of goods across borders, the Parties envisage comprehensive arrangements that will create a free trade area, combining deep regulatory and customs cooperation, underpinned by provisions ensuring a level playing field for open and fair competition

\footnotetext{
${ }^{71}$ Menon [30].

72 Weatherill [36], p. 165.

${ }^{73}$ Political Declaration, para. 2; Article 15 EU Council Negotiating Guidelines.

${ }^{74}$ Armstrong [1], p. 1113.
} 
(emphasis added). ${ }^{75}$ Though the Declaration insists that the UK and EU will be 'distinct legal orders', ${ }^{76}$ it may be strongly inferred that 'a level playing field and open and fair competition' are essential EU conditions for market access and which necessitates regulatory alignment and mutual recognition of both standards and practices, as well as application of a non-discrimination principle. This is further reinforced by paragraphs 24-25 of the Declaration, in which the parties will 'put in place provisions to promote regulatory approaches that are transparent, efficient, promote avoidance of unnecessary barriers to trade in goods and are compatible to the extent possible (emphasis added)'.

As Brexit entails taking back regulatory control, it will be politically difficult for the UK to accept mutual recognition with a dominance of EU standards, but this is, arguably, what the Declaration implies. ${ }^{77}$ The "removable of barriers to trade in goods' would, almost certainly, mean maintaining the dominance of existing Europeanised standards in a comprehensive trade relationship. ${ }^{78}$ This could result in, for example, de facto acceptance by the UK of inter alia, EU technical and sanitary and phytosanitary standards, which would probably include public policy objectives such as environmental and consumer protection, to secure Single Market access. Moreover, mutual recognition of these standards may also be insisted upon by the EU even if the UK only wants to negotiate a Canada-style FTA if it includes trade in live animals and a limited range of agri goods.

Ortino has argued that mutual recognition is one of the most important legal instruments in international and transnational regulation: 'Its basic function is to grant effect to foreign legal rules or acts occurring in the territory of another State. ${ }^{79}$ However, while mutual recognition may maximise Single Market access for UK business, it may have political implications by placing limits on regulatory choice for the UK with regulatory divergence being less likely for regulatory standards for goods. To take the example of arguably the most well-known technical specification mark, the "CE", found on most goods entering the Single Market. This is both a recognised 'kite mark' signifying the product satisfies EU technical standards and many consumers also consider it as a guarantee of the quality of the goods. ${ }^{80}$ Products manufactured in accordance with the technical standards are presumed to comply with EU minimum harmonisation requirements and may move freely throughout the EU. This creates commercial incentives for goods produced outside of the EU to conform to EU technical requirements. For example, this is why toys made in China will often bear the "CE" mark.

The CE Mark demonstrates the economic dominance of EU regulatory standards, their global reach and market power of the Single Market which makes it commer-

\footnotetext{
${ }^{75}$ Political Declaration, para 22.

${ }^{76}$ Political Declaration, para 21. See also Menon [30].

${ }^{77}$ A point reinforced by EU Commissioner Phil Hogan in his Irish Times interview of 30 December 2019 [24].

${ }^{78}$ Kukovec [27].

${ }^{79}$ Ortino [31], p. 309.

${ }^{80}$ Weatherill [35], p. 126.
} 
cially viable for non-EU countries to comply with EU regulatory standards. ${ }^{81}$ For the UK, this will require a policy choice of how much Single Market access the UK wants to have post Brexit, a decision which will be crucial given the volume of UK-EU trade and the importance of just in time supply chains which the Political Declaration recognises. ${ }^{82}$ The dominance of EU regulatory standards, and the UK's continuing need for regulatory alignment, is perhaps most acutely evident in the event of the UK and EU not agreeing a comprehensive trade deal before the end of the transition period on 31 December 2020. Without an agreement that goes beyond an FTA, the CE mark would cease to be applicable in the UK and with it just in time supply chains probably could not function.

In its place the government has proposed the UKCA (UK Conformity Assessed) marking for certain goods which are currently subject to CE marking and which are being placed only on the UK market. ${ }^{83}$ However, the UKCA marking will not be mutually recognised on the EU market, and products currently requiring a $\mathrm{CE}$ marking will continue to require a $\mathrm{CE}$ marking for sale in the EU, potentially placing a dual regulatory burden on UK business. If the UK fails to agree a trade deal, or potentially even an FTA, the results of conformity assessment carried out by UK notified bodies, currently mandated by EU legislation, would no longer be recognised in the EU. In practice this would mean that where EU legislation requires conformity to be assessed by a notified body, the manufacturer of the product must have their products assessed by an EU recognised notified body, in an EU member State, in order to continue to sell those goods in the EU, thereby removing regulatory autonomy from the UK for placing goods on the EU market. The practical effect of a dual regulatory burden will be a likely increase in production costs and reduced Single Market access.

The example of the CE mark as a mutual recognition mechanism enabling effective Single Market access encapsulates the regulatory and political dilemmas facing the UK of whether it only negotiates an FTA. This dilemma is further complicated by the market behaviour of multi-nationals, whose priorities are maximum market access and avoidance of dual regulatory burdens. With these priorities, it is ultimately open for business to determine its own regulatory preferences by adopting a 'competitive' approach towards regulatory governance ${ }^{84}$ and could constitute a key mechanism for regulatory policy transfer after Brexit. Business could express its regulatory preferences, which would be determined by the influence and attraction of market mechanisms that allows for dissemination of EU rules and norms beyond the jurisdictional territory of the EU. ${ }^{85}$ In the context of Brexit, this may include the market behaviour of multinational actors who either choose to relocate their manufacturing plants or to continue voluntarily compliance with EU rules, even in their non-EU

\footnotetext{
${ }^{81}$ Armstrong [1], p. 1105.

${ }^{82}$ Political Declaration, para. 16.

${ }^{83}$ See Department for Business, Energy and Industrial Strategy 'Prepare to use the UKCA mark after Brexit' available at https://www.gov.uk/guidance/prepare-to-use-the-ukca-mark-after-brexit. (Accessed 22 October 2019) [17].

${ }^{84}$ Armstrong [1], p. 1109.

${ }^{85}$ Bradford [4], p. 23.
} 
market activities. ${ }^{86}$ Practically, this could mean that UK government policy choices are overridden by the market power of multi-nationals. In their pursuit of market access, regulatory competition may lead UK business to either voluntarily maintain regulatory alignment with EU rules or provide for innovative divergence by exercising their market power and preferences independently of the regulatory policies of the UK.

\section{Regulatory oversight of the future UK-EU relationship}

A requirement of regulatory governance are effective oversight and enforcement arrangements. As the White Paper identifies, effective governance is essential, and it would be likely to include two core institutions; a 'Governing Body' that represents the EU Member States and UK $^{87}$ and a 'Joint Committee' which would exercise an oversight management role. ${ }^{88}$ This proposed institutional arrangement is similar to the Withdrawal Agreement ${ }^{89}$ arrangements where the Joint Committee oversees the implementation and management of the Withdrawal Agreement and the decisions of the Joint Committee are binding on both parties. However, the Joint Committee's role is limited to the Withdrawal Agreement and its oversight of regulatory compliance by the UK for the duration of the transition period. During this time, substantive law in the Withdrawal Agreement remains subject to EU law, ${ }^{90}$ and includes oversight of UK regulatory compliance by EU institutions, agencies and judicial oversight exclusively by the CJEU.

\subsection{Institutional challenges for the oversight of the future trade relationship}

Once the transition period ends the Withdrawal Agreement no longer covers disputes on points of substantive law and, as the Political Declaration indicates, the relationship would be governed by the institutional and governance arrangements agreed in the negotiations on the future relationship. At the commencement of the negotiations there is uncertainty about both the scope of the future trade relationship and institutional design of governance arrangements. But, if it is accepted that fundamental EU regulatory principles and objectives, within the Political Declaration are largely nonnegotiable, ${ }^{91}$ the challenges facing the UK may begin to be identified. In particular, Article 15 of the European Council Guidelines is most indicative of the regulatory issue facing the UK with respect to oversight of the future relationship and concerns

\footnotetext{
${ }^{86}$ IPT stakeholder seminar on 'Achieving EU Data Protection Equivalence after Brexit: Protecting CrossBorder Trade', UK Parliament, 24 January 2018.

${ }^{87}$ This institution would broadly replicate the role of the European Council and provide executive political direction under the future relationship.

${ }^{88} \mathrm{At}$ the start of the negotiations it is unclear what would be the precise function and remit of such a 'Joint Committee' and this will be largely dependent upon whether the UK and EU share a common rulebook.

${ }^{89}$ Article 164 Withdrawal Agreement.

${ }^{90}$ Article 126 Withdrawal Agreement.

${ }^{91}$ As strongly indicated by para. 79 .
} 
the autonomy of the EU legal order, including the role of the CJEU in interpretation and application of the Treaty.

The key governance challenges are therefore likely to come in the forms of management, dispute resolution and enforcement, which Article 15 strongly indicates should be based upon Europeanised governance principles and values. To adopt the regulatory analysis of Börzel and Risse, ${ }^{92}$ Article 15 emphasises the EU external policy of dominance of its governance principles through which it 'diffuses' these principles beyond the EU's borders via agreements with third countries. ${ }^{93}$ For the EU, this negotiating position makes sense, especially in the light of the public policy objectives laid out in Article 12 and 15 of the Council Guidelines, and reinforced by Article 128 of the Political Declaration that the future relationship will 'fully respect the autonomy of the EU legal order' and 'the position of the CJEU as the sole arbiter of EU laws'. 94

This would place the role of a Joint Committee front and centre of oversight and decision-making where it will ensure mutuality and adherence to the UK-EU Treaty. ${ }^{95}$ To this end the final agreement could even include 'constitutional' provisions that impose obligations of 'sincere cooperation', not dissimilar from those found in Article 4(3) TEU. Institutionally, a Joint Committee will be pivotal especially if it, and not the UK Parliament, determines whether the UK will adopt EU law as part of a common rulebook under the future trade relationship. If enacted, this form of governance would be a significant change for the UK Parliament which may have only a limited direct supervisory role, if any, over the work of the Joint Committee. ${ }^{96}$

Parliament would be arguably in a weaker constitutional position ${ }^{97}$ than, for example, under the pre-Brexit subsidiarity monitoring arrangements under Protocols $1^{98}$ and $2^{99}$ TEU and would need to devise new scrutiny arrangements to exercise effective control and influence over the government, prior to taking decisions within the Joint Committee. ${ }^{100}$ But, such parliamentary scrutiny could not detract from criticism that, far from 'taking back control' the UK has become a 'rule taker'. UK parliamentary scrutiny of draft EU legislative proposals would not be able to influence the substance of the proposal because the UK, as a third country, would have not participated in the legislative process.

The Political Declaration recognises that effective dispute resolution mechanisms are essential and provides for consultation and mediation, as a first step towards seek-

\footnotetext{
${ }^{92}$ Börzel and Risse [5], p. 9.

${ }^{93}$ Armstrong [1], p. 1007; Kukovec [27].

${ }^{94}$ Political Declaration, para. 131.

${ }^{95}$ Political Declaration, para. 128.

${ }^{96}$ Interviews on Brexit and parliamentary scrutiny with parliamentary official, Westminster, 4 June 2018, conducted by Philip Lynch and Richard Whitaker.

${ }^{97}$ Cygan, Lynch and Whitaker (2020, forthcoming) [15].

${ }^{98}$ Protocol on the role of national Parliaments in the European Union.

${ }^{99}$ Protocol on the application of the principles of subsidiarity and proportionality.

${ }^{100}$ Interview on Brexit and parliamentary scrutiny with committee clerk, Westminster, 5 December 2017, conducted by Adam Cygan, Philip Lynch and Richard Whitaker.
} 
ing a resolution. ${ }^{101}$ In the case of no resolution the Political Declaration proposes that a dispute may be referred to an independent arbitration panel, the decision of which will be binding upon both parties. ${ }^{102}$ However, the Political Declaration also recognises the autonomy principle of EU law, ${ }^{103}$ which, together with the Council's political position, would appear to put the CJEU in a predominant position with respect to judicial oversight of a Joint Committee, especially with respect to the interpretation and application of EU laws which form part of a common rulebook.

The UK is unlikely to agree to the CJEU undertaking this role exclusively, notwithstanding paragraph 131 of the Political Declaration, but it is hard to see the EU recoiling from this position. This is because the Joint Committee, as a non-EU body, would not be able to, in the words of the CJEU in Opinion 1/91, 'interpret provisions in substance identical to EU law'. ${ }^{104}$ In this case, a Joint Committee could not make decisions which may have any effect on the application or interpretation of EU jurisprudence or restrict the CJEU's interpretation of rights within the Treaties. This was one reason why, in Opinion 2/13 on EU Accession to the ECHR, ${ }^{105}$ the CJEU rejected the accession protocol because it was concerned that the European Court of Human Rights could challenge the autonomy and jurisdiction of the CJEU and make EU rights subject to external judicial control and interpretation. ${ }^{106}$

Compliance and enforcement of adopted EU laws therefore raises new accountability challenges for the UK within the governance framework of a future relationship. ${ }^{107}$ This includes Parliament's ability to effectively scrutinise EU legislative proposals that the UK may be bound to adopt as part of a common rulebook, and, the new institutional arrangements which determine whether a legislative proposal falls within the scope of the common rulebook. Though possible alternative solutions exist to a Joint Committee, for example the EFTA Surveillance Authority carries out a similar role in the EEA and monitors the correct and timely application of EEA law. However, this 'off the shelf' solution would require the UK to join the EEA, adopt Single Market rules ${ }^{108}$ and accept the continuing jurisdiction of the CJEU ${ }^{109}$ which is why EEA membership was rejected. ${ }^{110}$

\footnotetext{
${ }^{101}$ Political Declaration, para. 129.

${ }^{102}$ Political Declaration, para. 130.

${ }^{103}$ Reinforced strongly in para. 131 of the Political Declaration.

${ }^{104}$ Opinion 1/91, 14 December 1991. ECLI:EU:C:1991:490.

${ }^{105}$ Opinion 2/13, 18 December 2014. ECLI:EU:C:2014:2454.

${ }^{106}$ Opinion 2/13, paragraph 194.

${ }^{107}$ Interviews on scrutiny of EU/EEA issues by the Norwegian parliament with Storting officials, Oslo, 20 March 2019, conducted by Adam Cygan and Philip Lynch.

${ }^{108} \mathrm{An}$ issues that was stressed in interviews on scrutiny of EU/EEA issues by the Norwegian parliament with Storting officials, Oslo, 20 March 2019, conducted by Adam Cygan and Philip Lynch.

${ }^{109}$ Cygan, Lynch and Whitaker (2020, forthcoming) [14].

${ }^{110}$ See Theresa May's Lancaster House Speech 'The government's negotiating objectives for exiting the EU' 17 January 2017.
} 


\section{Concluding remarks}

'Getting Brexit Done' ${ }^{\text {'11 }}$ with its repatriation of competences to the UK Parliament and leaving the EU institutions may be presented as political de-Europeanisation. But, as this article demonstrates this is an oversimplification of what legal or regulatory de-Europeanisation entails, because the influence and reach of EU law will not end on 31 January 2020, or even at the conclusion of the transition period.

In the negotiations on the future trade relationship, four years since the 2016 Referendum and the polarised and simplistic arguments of 'leave or 'remain', the UK confronts the political, economic and regulatory effects of Brexit. As this article has argued, the UK will need to take difficult decisions about the extent of regulatory alignment it will accept to maintain a high degree of Single Market access and which parts of the non-binding Political Declaration the UK is prepared to accept as being legally binding. If the UK chooses to maximise Single Market access, through a comprehensive trade agreement, it almost certainly would require a common rulebook and the UK becoming a rule taker. In such circumstances this is likely to maintain an Europeanised framework of regulatory governance in the UK, which remains subject to CJEU interpretations, a principle of mutual recognition and continued adherence to EU public policy standards and values. By contrast, a Canada-style FTA would require minimal regulatory alignment, but provide very limited market access.

Throughout EU membership the UK has exercised regulatory autonomy to the extent that the EU Treaties do not have competence or where it has chosen a regulatory framework that goes beyond minimum harmonised standards. Simultaneously, the UK has advocated better EU governance, for example, placing the EU Better Regulation Agenda as a central objective of it 2005 Presidency of the Council. The UK also exercised policy influence in, for example, EU environmental regulation where it has strongly advocated higher policy ambitions in climate change. ${ }^{112}$ Conversely, it has also argued for fewer EU rules in employment policy which the UK consistently maintained should be areas of national competence. ${ }^{113}$ This historical antagonism to EU competence in employment policy further indicates the likelihood of some future divergence of UK employment laws.

Overall, the UK has been an involved actor in EU governance and it is unlikely that this 'internationalist' and engaged approach will end with Brexit. However, this will be much harder to achieve, and the UK will need to rely on good bilateral relations with Member States that may be sympathetic to UK's views on future EU laws it may be required to adopt as part of a common rulebook. While such 'soft power' may come to be an important avenue of continued dialogue with EU Member States it will undoubtedly be less influential in shaping EU regulatory governance than having UK representation within the EU institutions. ${ }^{114}$

\footnotetext{
${ }^{111}$ Conservative Party Manifesto, November 2019. 'Getting Brexit Done: Unleash Britain's Potential' [12]. (Accessed 30 November 2019).

${ }^{112}$ Burns et al. (2019) [7], p. 277.

${ }^{113}$ Case C-84/94 Working Time Directive ECLI:EU:C:1996:431.

${ }^{114}$ Interviews on scrutiny of EU/EEA issues by the Norwegian parliament with Storting officials, Oslo, 20 March 2019, conducted by Adam Cygan and Philip Lynch.
} 
Publisher's Note Springer Nature remains neutral with regard to jurisdictional claims in published maps and institutional affiliations.

Open Access This article is licensed under a Creative Commons Attribution 4.0 International License, which permits use, sharing, adaptation, distribution and reproduction in any medium or format, as long as you give appropriate credit to the original author(s) and the source, provide a link to the Creative Commons licence, and indicate if changes were made. The images or other third party material in this article are included in the article's Creative Commons licence, unless indicated otherwise in a credit line to the material. If material is not included in the article's Creative Commons licence and your intended use is not permitted by statutory regulation or exceeds the permitted use, you will need to obtain permission directly from the copyright holder. To view a copy of this licence, visit http://creativecommons.org/licenses/by/4.0/.

\section{References}

1. Armstrong, K.A.: Regulatory alignment and divergence after Brexit. J. Eur. Public Policy 25(8), 1099_ 1117 (2018)

2. Bertea, S.: Looking for coherence within the European Community. Eur. Law J. 11(2), 154-172 (2005)

3. Birch, S., Bulmer, M.: The Europeanization of UK government: from quiet revolution to explicit step-change? Public Adm. 83(4), 861-890 (2005)

4. Bradford, A.: The Brussels effect. Northwest. Univ. Law Rev. 107(1), 1-67 (2012)

5. Börzel, T.A., Risse, T.: From Europeanisation to diffusion: introduction. West Eur. Polit. 35(1), 1-19 (2012)

6. Boucon, L.: EU law and retained powers of member states. In: Azoulai, L. (ed.) The Question of Competence in the European Union, pp. 168-192. Oxford University Press, Oxford (2014). 2014

7. Burns, C., Gravey, V., Jordan, A., Zito, A.: De-Europeanising or disengaging? EU environmental policy and Brexit. Environ. Polit. 28(2), 271-292 (2019)

8. de Búrca, G., Scott, J.: Narrowing the gap? Law and new approaches to governance in the European Union. Columbia J. Eur. Law, Spec. Issue 13(3), 513-537 (2007)

9. Cm 9593: The Future Relationship between the United Kingdom and the European Union (2018)

10. COM (2001): 428 European Governance: A White Paper

11. COM (2003): 71 final Updating and simplifying the Community acquis

12. Conservative Party Manifesto: Getting Brexit Done: Unleash Britain's Potential (2019)

13. Copeland, P.: Europeanization and de-Europeanization in UK employment policy: changing governments and shifting agendas. Public Adm. 94(4), 1124-1139 (2016)

14. Cygan, A.: Public healthcare in the European Union: still a service of general interest? Int. Comp. Law Q. 57(4), 529-560 (2008)

15. Cygan, A., Lynch, P., Whitaker, R.: Parliamentary scrutiny of the legal and political space after Brexit. J. Common Mark. Stud. (2020, forthcoming)

16. Dehousee, R.: Misfits: EU law and the transformation of European governance. In: Joerges, C., Dehousse, R. (eds.) Good Governance in Europe's Integrated Marke, pp. 207-230. OUP, Oxford (2002)

17. Department for Business, Energy and Industrial Strategy 'Prepare to use the UKCA mark after Brexit'. (2019). Available at https://www.gov.uk/guidance/prepare-to-use-the-ukca-mark-after-brexit

18. Directive 2003/33/EC of the European Parliament and of the Council of 26 May 2003 on the approximation of the laws, regulations and administrative provisions of the Member States relating to the advertising and sponsorship of tobacco products

19. Elliott, M., Tierney, S.: Political pragmatism and constitutional principle: the European Union (Withdrawal) Act 2018. Public Law 53(1), 37-60 (2019)

20. EU Council Negotiation Guidelines for the future UK-EU relationship, EUCO XT 20001/18, 23 March 2018.

21. Harlow, C., Rawlings, R.: Law and Administration. Cambridge University Press, Cambridge (2009)

22. House of Lords: Ensuring effective regulation in the EU. 9th Report of Session 2005-2006

23. Institute for Government, Trade after Brexit: Options for the UK's relationship with the EU. (2017). https://www.instituteforgovernment.org.uk/sites/default/files/publications/IFGJ5896-Brexit-Report171214-final.pdf 
24. Irish Times interview with EU Commissioner Phil Hogan on 30 December 2019. Available at https://www.irishtimes.com/news/ireland/irish-news/johnson-will-abandon-pledge-on-brexittransition-period-hogan-1.4126850. Accessed 30 December 2019.

25. Jordan, A., Bauer, M.W., Green-Pedersen, C.: Policy dismantling. J. Eur. Public Policy 20(5), 795805 (2013)

26. Knill, C., Lehmkuhl, D.: The national impact of European Union regulatory policy: three Europeanization mechanisms. Eur. J. Polit. Res. 41(2), 255-280 (2002)

27. Kukovec, D.: Brexit and misconceptions of governance (2019). Available at https://ukandeu.ac.uk/ brexit-and-misconceptions-of-governance/

28. Lenaerts, K.: Interlocking legal orders in the European Union and comparative law. Int. Comp. Law Q. 52(4), 873-906 (2003)

29. Leucht, B.: The policy origins of the European economic constitution. Eur. Law J. 24(2), 191-205 (2018)

30. Menon, A.: An inflexible Brussels is damaging its own interests over Brexit. Financial Times. Available at https://www.ft.com/content/69edfca4-0633-11ea-a958-5e9b7282cbd1. Accessed 19 November 2019 .

31. Ortino, M.: The role and functioning of mutual recognition in the European market of financial services. Int. Comp. Law Q. 56(2), 309-338 (2007)

32. Political Declaration setting out the framework for the future relationship between the European Union and the United Kingdom (2019)

33. Walker, N., de Búrca, G.: Narrowing the gap? Law and new approaches to governance in the European Union. Columbia J. Eur. Law, Spec. Issue 13(3), 519-545 (2007)

34. Weatherill, S.: Pre-emption, harmonisation and the distribution of competence to regulate the internal market. In: Barnard, C., Scott, J. (eds.) The Law of the Single Market: Unpacking the Premises, pp. 229-256. Hart, Oxford (2002)

35. Weatherill, S.: EC Consumer Law and Policy. Edward Elgar, Cheltenham (2005)

36. Weatherill, S.: The several internal markets. Yearb. Eur. Law 36, 125-178 (2017) 